\title{
MIR215 pre-miRNA
}

National Cancer Institute

\section{Source}

National Cancer Institute. MIR215 pre-miRNA. NCI Thesaurus. Code C95040.

MIR215 pre-miRNA (110 bases) is encoded by the human MIR215 gene. This ribonucleotide may play a role in the regulation of transcription. 